\title{
Sliding Wear Study of Flame Sprayed Co-Base Powder Coatings
}

\author{
Sushil Kumar ${ }^{1}$ and Satpal Sharma ${ }^{2, *}$ \\ ${ }^{1}$ Naraini Group of Institutions, Chirao, Karnal, Haryana, India \\ ${ }^{2}$ School of Engineering, Gautam Buddha University, Greater Noida, UP, India
}

\begin{abstract}
Commercially available Co-base powder was modified with the addition of $10 \mathrm{wt}$. percentage WC which was further modified with 5 and 10 wt. percentage $\mathrm{CrC}$ addition in order to obtain three coatings namely $\mathrm{Co}+10 \mathrm{wt}$. percentage $\mathrm{WC}, \mathrm{Co}+10 \mathrm{wt}$. percentage $\mathrm{WC}+5$ wt. percentage $\mathrm{CrC}$ and $\mathrm{Co}+10$ wt. percentage $\mathrm{WC}+10 \mathrm{wt}$. percentage $\mathrm{CrC}$. The coatings were deposited by flame spraying process. The microstructure of these coatings mainly showed eutectic containing Co with almost same amount in three coatings. Other phases such as $\mathrm{W}$ dominated and $\mathrm{Cr}$ dominated carbides were also observed. The $10 \mathrm{wt}$. percentage $\mathrm{CrC}$ coating showed the highest Vickers hardness and lowest wear rate. The coefficient of friction was also observed low in the 10 wt. percentage $\mathrm{CrC}$ coating as compared with other coatings.
\end{abstract}

Received on 05-03-2014 Accepted on 28-08-2014 Published on 30-10-2014

Keywords: Co-base, Flame spraying, Microstructure, Hardness, Adhesive wear.

\section{INTRODUCTION}

The deterioration of equipment parts, such as wear, corrosion, and high-temperature oxidation, usually begins at their surfaces when they work under high temperature, high pressure, and corrosive conditions. Surface engineering is a cost-efficient method for producing materials, tools, and machine parts that must resist severe wear conditions. Improvement of the surface properties by thermal spraying of a hard and wear resistant material is a commonly used industrial practice [1-3].

Various thermal spraying techniques can be used to achieve the best combination of coating and substrate properties for industrial applications. Nowadays, advances in thermal spraying make possible the replacement of bulk components in paper milling [4] or the replacement of chromium plating in aircraft manufacturing $[5,6]$ and automotive industry $[7,8]$. Also the deposition of thermally sprayed coatings on critical parts in petroleum drilling [9] or on components in aeroapplications such as fans and high-pressure compressors $[10,11]$ were successful using flame spraying, detonation gun spraying (D-Gun), high velocity oxygen fuel (HVOF), and atmospheric plasma spraying (APS).

In wear-resistant applications, the coated layer provides the resistance to wear, while the substrate supports the impact to which the system (coating and substrate) is subjected.

"School of Engineering, Gautam Buddha University, Greater Noida, UP, India; Tel: 01202346001; E-mail: satpal78sharma@gmail.com
Coating materials such as cobalt, iron and nickel base alloys with hard carbide particles (WC and $\mathrm{CrC}$ ) are used to improve the wear resistance in various industrial applications [12-15].

Various researchers [16-18] studied the effect of varying amount of various types of carbides in Ni-base coating. The proportion of carbide particles in the nickel alloy matrix increases the microhardness of the coating, with the nickel matrix providing the desired toughness. The hardness of the alloy coatings also depends on microstructural parameters, such as fraction of soft matrix and type and fraction of carbide particles, size and shape of carbide particles and their stability, etc. Recently many studies [1-3, 12-16, 18-25] have been reported in the literature on the microstructure, microhardness, adhesive strength and adhesive wear behaviour of coatings with and without chromium carbide particles developed by different processes. Mateos et al. [20] investigated tribological properties of plasma sprayed and laser remelted $75 / 25 \mathrm{Cr}_{3} \mathrm{C}_{2} / \mathrm{NiCr}$ coatings and reported that laser remelting improves the microstructure of the coatings, increases the coating microhardness, and improves coatingsubstrate adherence. Dent et al. [23] investigated microstructural aspects of a $\mathrm{Ni}-23.5 \mathrm{Cr}-3.8 \mathrm{Cu}-0.8 \mathrm{Fe}-5.9 \mathrm{Mo}-$ $3.4 \mathrm{~W}-2.8 \mathrm{~B}-4.3 \mathrm{C}$ alloy coating produced by high velocity oxyfuel thermal spraying and found that the splat microstructures consisted of a Ni-rich metallic matrix containing a small fraction of $\mathrm{M}_{23} \mathrm{C}_{6}$ particles. Dawei et al. [25] studied laser clad coatings of $\mathrm{Ni}$ alloys as well as composites containing $50 \mathrm{wt}$. percentage $\mathrm{Cr}_{3} \mathrm{C}_{2}$ particles in $\mathrm{Ni}-\mathrm{Cr}$ alloy and found increased 
Table 1: Chemical Composition (wt. \%) of Substrate and Surfacing Powder

\begin{tabular}{|c|c|c|c|c|c|c|c|}
\hline & Elements (wt. percentage) \\
Coating Powder $\downarrow$ & C & Cr & W & Si & Fe & & \\
\hline \hline Substrate & $0.2-0.22$ & - & - & $0.4-0.6$ & Bal. & - & $0.4-0.8$ \\
\hline Coating Powder & $3.0-3.5$ & $28-30$ & $5-6$ & $0.2-0.5$ & - & Bal. & $0.5-0.7$ \\
\hline
\end{tabular}

hardness of the surface layer by $350-400 \mathrm{HV}$. The presence of undissolved $\mathrm{Cr}_{3} \mathrm{C}_{2}$ particles, the formation of dense dendrites surrounded by a fine eutectic containing carbide and borides which were found responsible for the strengthening of the composite coating.

Wang et al. [26] studied the performance of WC-Co coatings deposited by detonation gun spraying system. The results showed that the use of the separation device resulted in better properties of the D-gun sprayed WC-Co coatings in terms of lower the surface roughness, lower the porosity, higher the microhardness. Also, the tribological performance of the WC-Co coatings was improved. The relationship of surface roughness, microhardness and wear resistance of the WC-Co coatings was discussed.

The aim of the research carried by Sarjas [27] was to study properties of composite powders based on self-fluxing alloys and recycled cermets and to examine the properties of thermally sprayed (HVOF) coatings from composite powders based on iron self-fluxing alloy and recycled cermet powders $\left(\mathrm{Cr}_{3} \mathrm{C}_{2}-\mathrm{Ni}\right.$ and $\left.\mathrm{WC}-\mathrm{Co}\right)$. The structure and composition of powders and coatings were estimated by SEM and XRD methods. Abrasive wear performance of coatings was determined and compared with wear resistance of coatings from commercial powders. The wear resistance of thermal sprayed coatings from self-fluxing alloy and recycled cermet powders at abrasion is comparable with wear resistance of coatings from commercial expensive spray powders and may be an alternative in tribological applications in cost-sensitive areas.

The literature did not reveal studies on the effect of WC and $\mathrm{CrC}$ addition in Co-base alloy coatings developed by flame spraying process on their microhardness and adhesive wear. Therefore, to fill up this gap, in the present study, attempts have been made to investigate the influence of $\mathrm{WC}$ and $\mathrm{CrC}$ particle addition on microstructure, microhardness and adhesive wear behavior of Co-base coatings deposited by flame spraying method on low carbon steel substrate.

\section{EXPERIMENTAL PROCEDURE}

\subsection{Materials and Methods}

The carbon steel substrate was used for coating deposition. The normal composition of substrate is shown in Table 1. The substrate was degreased and roughened to an average surface roughness of $\mathrm{Ra} 4.05 \mu \mathrm{m}$ (Rmax $18.5 \mu \mathrm{m})$. Surface roughness was measured by Mahr - Perthometer $\left(M_{2} 409\right)$. The normal composition of the commercially available Cobase powder is shown in Table 1. This powder was modified by adding $10 \mathrm{wt}$. percentage WC. The WC containing powder was further modified with $5 \mathrm{wt}$. percentage $\mathrm{CrC}$ and $10 \mathrm{wt}$. percentage $\mathrm{CrC}$ (chromium carbide). In this way three coating powders namely $\mathrm{Co}+10 \mathrm{wt}$. percentage WC, Co+10 wt. percentage $\mathrm{WC}+5 \mathrm{wt}$. percentage $\mathrm{CrC}$ and $\mathrm{Co}+10 \mathrm{wt}$. percentage $+10 \mathrm{wt}$. percentage $\mathrm{CrC}$ were obtained. These coating powders were deposited by flame spraying process and corresponding coatings in further discussion were designated as Co+10 wt. percentage WC, Co+10 wt. percentage $\mathrm{WC}+5$ wt. percentage $\mathrm{CrC}$ and $\mathrm{Co}+10$ wt. percentage $\mathrm{WC}+10 \mathrm{wt}$. percentage $\mathrm{CrC}$ coatings.

\subsection{Porosity and Hardness of Flame Sprayed Coatings}

The porosity was measured by the point counting method $[13,14]$. The average of 25 areas of each coating has been used for porosity measurement. Vickers microhardness of the coatings was measured using a load of $100 \mathrm{~g}$ and average of ten readings of the coating was used for study purpose [16, 17].

\subsection{Wear Test}

Friction and wear tests were conducted on a pin-on-disk tribometer. This machine is capable of providing wear data and friction force at different sliding speeds and loads with respect to time and digital display devices are used for monitoring the various parameters. The load on the pin specimen is applied by dead weights supported at the end of a hinged horizontal arm. The wear weight loss was measured by electronic analytical balance [9].

The test pin of size $10 \times 10 \times 100 \mathrm{~mm}^{3}$ was inserted in a pin holder and cleaned with acetone. The coated discs (cast iron) were ground to obtain a surface roughness, $\mathrm{Ra}$, between 0.6 and $0.8 \mu \mathrm{m}$. The pin holder and disk were then mounted in the machine and the disk was cleaned with acetone. A fresh disk surface was used for each test. After the load was applied, all display devices were balanced and the computer was turned on. Before starting the machine the radius of the pin (wear track radius) was set in order to obtain the desired sliding distance of $3000 \mathrm{~m}$ (50 minutes test duration). Next, the machine was turned on to obtain the desired speed and afterwards the load was applied. The constant sliding speed is $1 \mathrm{~ms}-1$ and the normal load applied to the disc was 4,8 and $12 \mathrm{~N}$. The friction coefficient was computer-monitored 
during the test. Three tests were performed for each condition and the results reported as an average value. The COF was recorded after 10,25 and 40 minutes during each test and average value is used for study. All tests were performed on pin-on-disc tribometer under dry sliding at room temperature $\left(25{ }^{\circ} \mathrm{C}\right)$.

\section{RESULTS AND DISCUSSIONS}

\subsection{Microstructure}

The microstructure of $\mathrm{Co}+10 \mathrm{wt}$. percentage WC, Co+10 wt. percentage $\mathrm{WC}+5$ wt. percentage $\mathrm{CrC}$ and $\mathrm{Co}+10$ wt. percentage $\mathrm{WC}+10 \mathrm{wt}$. percentage $\mathrm{CrC}$ coatings are shown in Figure 1a-c. The microstructure of $\mathrm{Co}+10 \mathrm{wt}$. percentage WC coating mainly showed eutectic (phase "A") and various types of carbide particles (phase "B" and "C"). The eutectic (phase "A") mainly composed of $\mathrm{Co}, \mathrm{Ni} \mathrm{Cr}, \mathrm{W}, \mathrm{Fe}$ and $\mathrm{C}$. EDAX analysis of eutectic (phase "A") shows that is contains $\approx 30 \% \mathrm{Co}, \approx 24 \% \mathrm{Ni}$ and $\approx 15 \%$ Fe along with other elements such as $8 \% \mathrm{Cr}, 6 \% \mathrm{~W}$ and $5 \% \mathrm{C}$. From the EDAX analysis of various phases " $\mathrm{B}$ " and " $\mathrm{C}$ ", it was concluded that these phases primarily differ in terms of relative amounts of various elements such as $\mathrm{W}, \mathrm{Cr}$ and Co etc. The phase " $\mathrm{B}$ " is $\mathrm{W}$ dominated and analysis of this phase shows $67 \% \mathrm{~W}, \sim 6 \% \mathrm{Co}$, $\sim 7 \% \mathrm{Cr}$ and $\sim 7 \% \mathrm{Ni}$ and $4 \% \mathrm{C}$ (\%wt). Cr dominated carbides
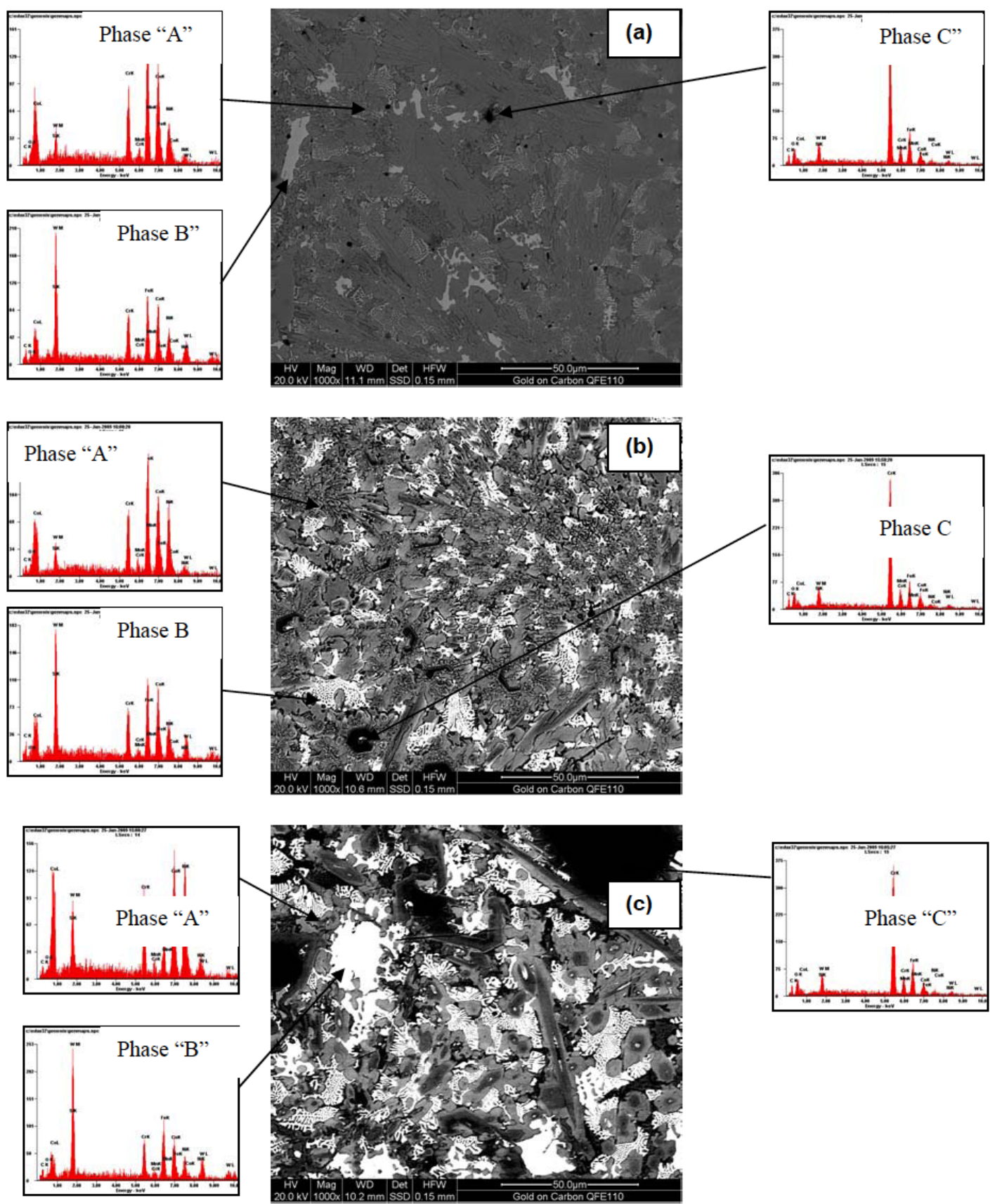

Figure 1: Microstructure and EDAX analysis of (a) Co+10\%WC (b) Co $+10 \% \mathrm{WC}+5 \% \mathrm{CrC}$ and (c) Co $+10 \% \mathrm{WC}+10 \% \mathrm{CrC}$. 
(phase "C") are rich in $\mathrm{Cr}$ and contains $\approx 62 \% \mathrm{Cr}, \approx 13 \% \mathrm{~W}$, $\approx 12 \% \mathrm{Co}, \approx 9 \% \mathrm{C}$ and small amounts of $\mathrm{Ni}$ and $\mathrm{Fe}(<5 \%)$.

The wt. percentage of Co $(30 \%)$ is same in the matrix in all the three coatings and it is uniformly distributed in the matrix. The wt. percentage of $\mathrm{Cr}$ increases (from 8-14 wt. percentage) with the increase of $\mathrm{CrC}$ addition. The other elements such as $\mathrm{Ni}, \mathrm{Cr}$ and $\mathrm{Fe}$ are also uniformly distributed in the matrix. These results are in agreement with Shetty et al. that the matrix is rich in Co containing various types of carbides uniformly distributed in the matrix. Some carbide such as ( $\mathrm{Cr}$ rich) appears darker in SEM images. This observation is also in line with the Shetty et al. [28].

In the $\mathrm{Co}+10 \mathrm{wt}$. percentage $\mathrm{WC}+5$ wt. percentage $\mathrm{CrC}$ coating both types of carbides (W dominated - phase "B" and $\mathrm{Cr}$ dominated - phase "C") contains almost same compositions of various elements. But in $\mathrm{Co}+10$ wt. percentage $\mathrm{WC}$ and $\mathrm{Co}+10 \mathrm{wt}$. percentage $\mathrm{WC}+10 \mathrm{wt}$. percentage $\mathrm{CrC}$ coatings the $\mathrm{W}$ dominated carbides (phase "B") contains higher wt. percentage of $W$ as compared to phase " $\mathrm{C}$ " which is $\mathrm{Cr}$ dominated carbides and also contains $\mathrm{W}$. The carbides are not pure phases but also contain $\mathrm{Ni}, \mathrm{Co}$ and Fe. This is in agreement with Chorcia et al. [29].

The alloy in this investigation is hypereutectic alloy and comprises various types of chromium-carbide in which some of the chromium may be replaced by cobalt and/or tungsten with a eutectic matrix containing the other constituents of the alloy. The higher hardness of $\mathrm{Co}+10 \mathrm{wt}$. percentage $\mathrm{WC}+10$ wt. percentage $\mathrm{CrC}$ coating as compared to other two $(\mathrm{Co}+10$ wt. percentage $\mathrm{WC}$ and $\mathrm{Co}+10 \mathrm{wt}$. percentage $\mathrm{WC}+5 \mathrm{wt}$. percentage $\mathrm{CrC}$ ) is due to formation of intermetallic compounds [30, 31]. According to Lebaili [32] alloys that present the highest amount of chromium and carbon crystallizes $\mathrm{Cr}_{7} \mathrm{C}_{3}$ first. The hardness of $\mathrm{Cr}_{7} \mathrm{C}_{3}$ and carbides is reported as 17.7 and $9.9 \mathrm{GPa}$ respectively.

\subsection{Porosity and Hardness of Flame Sprayed Coating}

The porosity of $\mathrm{Co}+10$ wt. percentage WC, Co+10 wt. percentage $\mathrm{WC}+5$ wt. percentage $\mathrm{CrC}$ and $\mathrm{Co}+10 \mathrm{wt}$. percentage $\mathrm{WC}+10 \mathrm{wt}$. percentage $\mathrm{CrC}$ coatings were found to be $6.8 \%, 7.5 \%$ and $8.4 \%$ respectively. The Vickers hardness $(\mathrm{Hv})$ of $\mathrm{Co}+10$ wt. percentage WC, Co+10 wt. percentage $\mathrm{WC}+5$ wt. percentage $\mathrm{CrC}$ and $\mathrm{Co}+10$ wt.

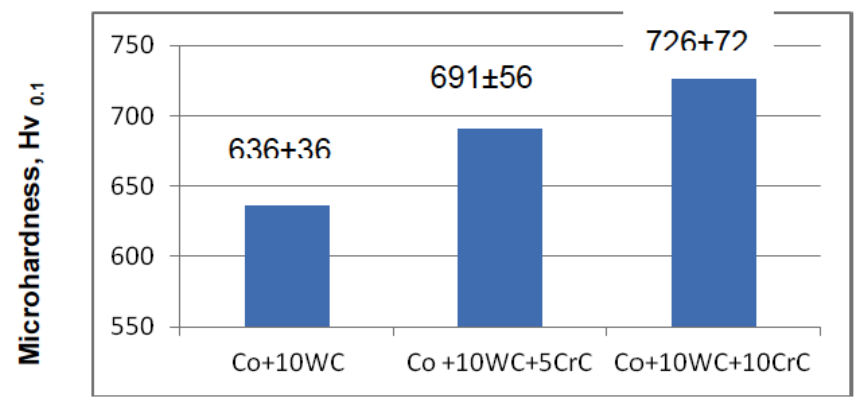

Figure 2: Microhardness of various coatings. percentage $\mathrm{WC}+10$ wt. percentage $\mathrm{CrC}$ coatings was found $636 \pm 36,691 \pm 56$ and $726 \pm 72$ respectively (Figure 2 ). The average hardness of $10 \mathrm{wt}$. percentage chromium carbide coating was found higher $(726 \mathrm{Hv})$ as compared to $0 \mathrm{wt}$. percentage chromium carbide $(636 \mathrm{Hv})$ and $5 \mathrm{wt}$. percentage chromium carbide $(691 \mathrm{Hv})$ coatings, however, there was more scatter in hardness of $10 \mathrm{wt}$. percentage chromium carbide coating as compared to 0 wt. percentage chromium carbide and $5 \mathrm{wt}$. percentage chromium carbide coatings may be due to higher porosity.

\subsection{Friction and Wear Analysis}

The wear and friction coefficient of $\mathrm{Co}+10 \mathrm{wt}$. percentage $\mathrm{WC}, \mathrm{Co}+10$ wt. percentage $\mathrm{WC}+5$ wt. percentage $\mathrm{CrC}$ and $\mathrm{Co}+10$ wt. percentage $\mathrm{WC}+10 \mathrm{wt}$. percentage $\mathrm{CrC}$ coatings are shown Figure $\mathbf{3 a - b}$. The wear rate decreases with the addition of $\mathrm{CrC}$ in $\mathrm{Co}+10$ wt. percentages WC coatings. The lowest wear rate was observed in $10 \mathrm{wt}$. percentage $\mathrm{CrC}$ coatings. This may be due to high hardness of the coating. The scanning electron microscope (SEM) images of the worn surfaces are shown in Figure 4a-c. The worn surfaces show a combination of adhesive and abrasive wear mechanisms. The adhesive wear and friction coefficient depends mainly on material composition and counter-body combinations, surface topography and operating conditions (contact mode, normal load and sliding speed, etc.). The rapid initial increase after the start of the wear test may be due to initially high adhesive contact between the counter body and coating material or adsorbed layer. There after there is slight decrease in the adhesive wear which may be due to work hardening of the coating material under compressive stresses [33]. After some time, the wear rate becomes stable and during this stage, the wear debris may be generated. These wear debris may adhere to the coating material or with the counter body which may become loose and transferred as wear debris. If these wear debris are entrapped in between the counter body and coating material may cause abrasive wear also (Figure 4a-c). This likely causes an increase in frictional force which in turn increases the friction coefficient again. In final stage, the process of newly generation and spallation of wear debris on the surface seems to reach steady-state [34].

For composite coating containing WC particles with high hardness protruding from the worn surface can bear more pressure on surface, thus effectively resist the micro-plowing and micro-cutting brought from counter body. Consequently, the composite coating shows higher wear-resistance. The abrasive nature of the tungsten carbide particles hinders the transfer of material between specimen and counter-body and consequently the severity of the contact is not widely altered. The abrasive properties of the hard tungsten carbide particles produce a large increase in the counter-body wear [35].

\section{CONCLUSIONS}

The following conclusions can be drawn from the present study: 
Journal of Coating Science and Technology, 2014, Volume 1, No. 2
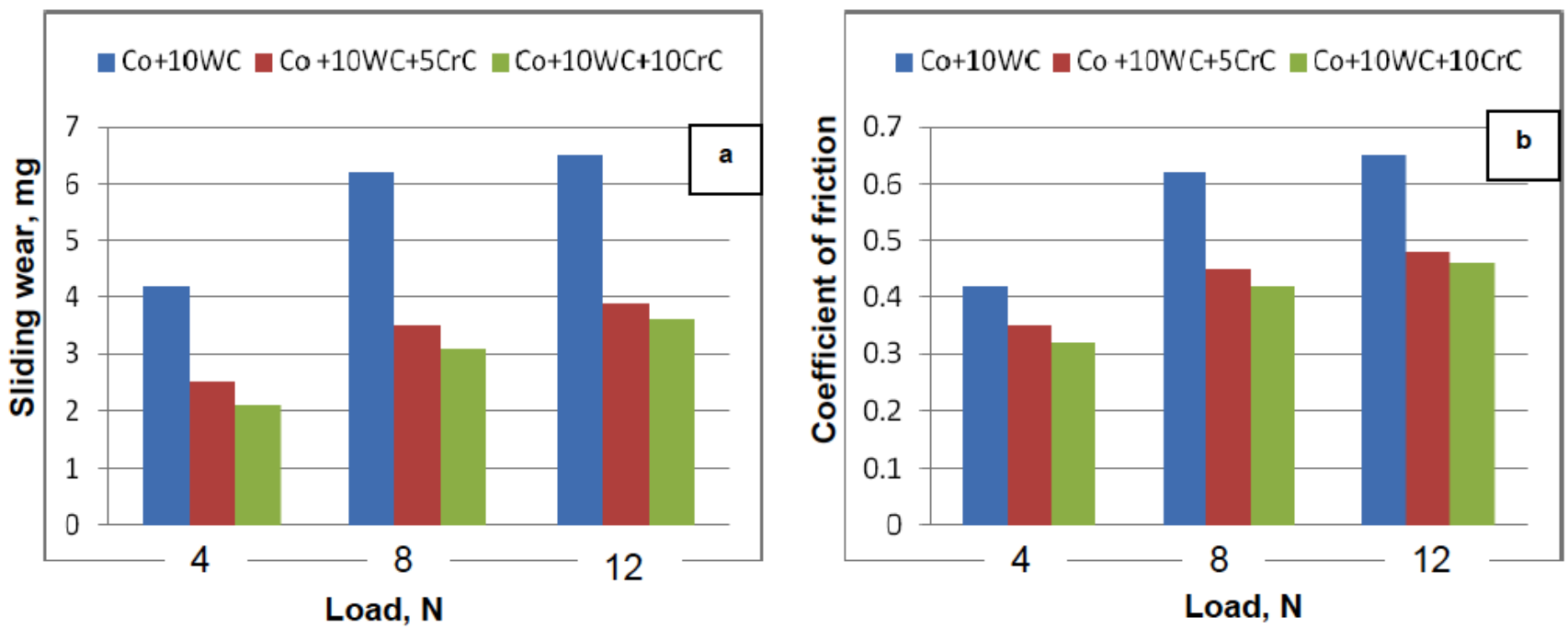

Figure 3: (a) Sliding wear as a function of load and (b) coefficient of friction as a function of load of various flame sprayed coatings.
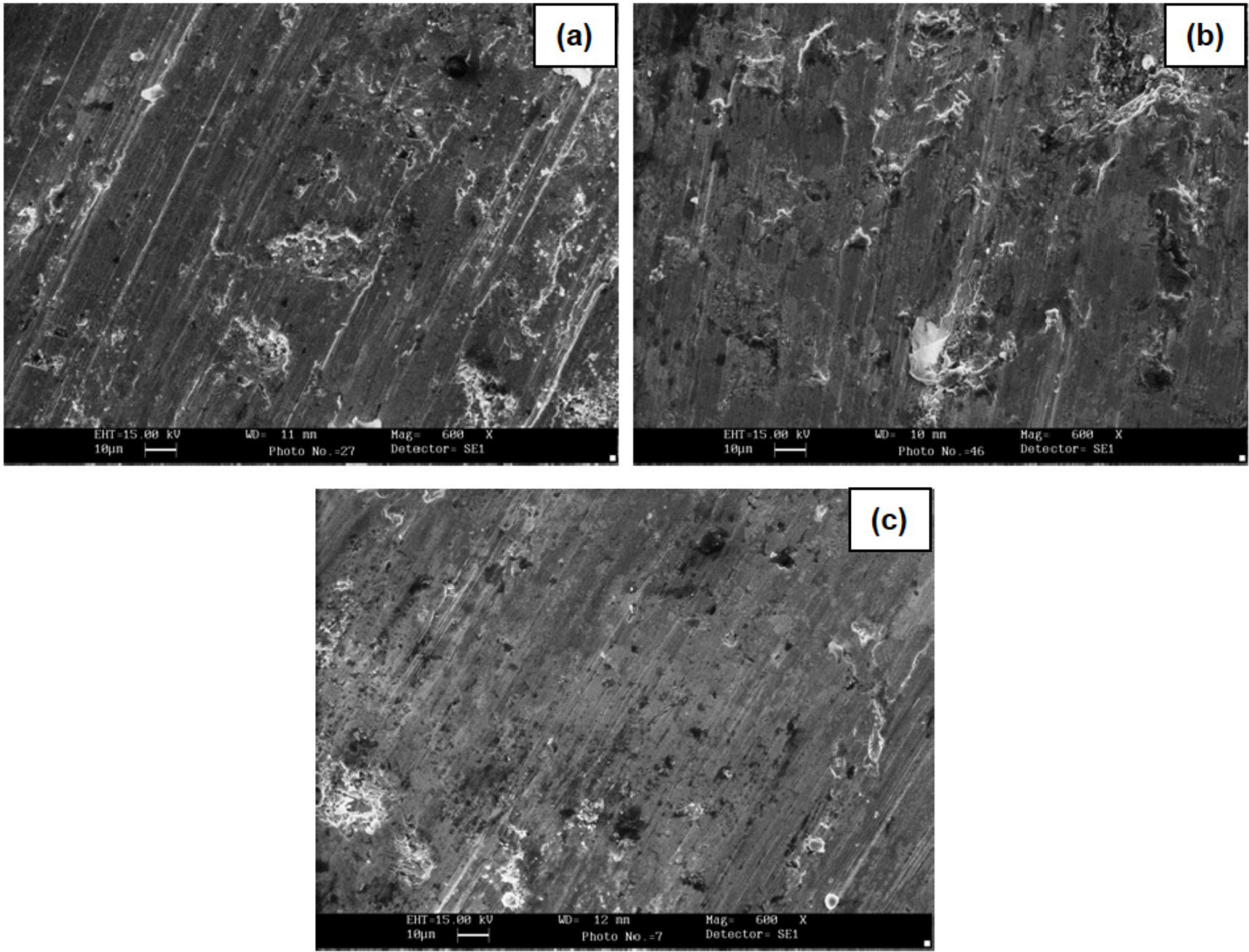

Figure 4: SEM images of worn surfaces of flame sprayed coatings at $8 \mathrm{~N}$ load (a) Co+10 wt. percentage WC, (b) Co+10 wt. percentage WC+5 wt. percentage $\mathrm{CrC}$ and (c) $\mathrm{Co}+10$ wt. percentage $\mathrm{WC}+10$ wt. percentage $\mathrm{CrC}$ coatings respectively.

1. The microstructure of $\mathrm{Co}+10 \mathrm{wt}$. percentage $\mathrm{WC}$, $\mathrm{Co}+10$ wt. percentage $\mathrm{WC}+5$ wt. percentage $\mathrm{CrC}$ and
Co+10 wt. percentage $\mathrm{WC}+10$ wt. percentage $\mathrm{CrC}$ coatings mainly showed three different phases namely 
eutectic, $\mathrm{W}$ dominated and $\mathrm{Cr}$ dominated carbides. The amount of $\mathrm{Co}$ in the eutectic of all the three coatings is almost same.

2. The Vickers hardness of the coatings increase with the increases in chromium carbide. The $10 \mathrm{wt}$. percentage $\mathrm{CrC}$ addition shows the highest hardness.

3. The 10 wt. percentage $\mathrm{CrC}$ coating showed the lowest adhesive wear which may be due to high hardness of this coating and a large increase in the counter-body wear.

4. The coefficient of friction initially increases rapidly but becomes stable after some time. The COF was also low in 10 wt. percentage $\mathrm{CrC}$ coating.

\section{REFERENCES}

[1] Ghosh PK, Dwivedi DK, Mishra PS. Studies on oxidation and wear resistance of hard surface produced by gas thermal spraying of modified nickel base eutectic alloy powder. Indian Weld J 2001; 34: $35-41$

[2] Miguel JM, Guilemany JM, Vizcaino S. Tribological study of NiCrBSi coating obtained by different processes. Tribol Int 2003; 36: 181-7. http://dx.doi.org/10.1016/S0301-679X(02)00144-5

[3] Kim HJ, Kim YJ. Wear and corrosion resistance of PTA weld surfaced $\mathrm{Ni}$ and Co based alloy layers. Surf Eng 1999; 15: 495. http://dx.doi.org/10.1179/026708499101516911

[4] Fritsch A, Gadow R, Killinger A. Development of Highly Wear Resistant Coatings for Deflector Blades in Paper Industry in Thermal Spray: Surface Engineering via Applied Research (Proceedings of ITSC 2000), C.C. Berndt, ed., ASM International, Materials Park, $\mathrm{OH}$, 2000, pp. 1051-55

[5] Strock E, Ruggiero P, Reynolds D. The Effect of Off-Angle Spraying on the Structure and Properties of HVOF $\mathrm{WC} / \mathrm{CoCr}$ Coatings in Thermal Spray 2001: New Surfaces for a New Millennium (Proceedings of ITSC 2001), C.C. Berndt, K.A. Khor, and E.F. Lugscheider, ed., ASM International, Materials Park, OH, 2001, pp. 671-76

[6] Nascimento MN, Souza RC, Miguel IM, Pigatin WL, Voorwald HJC. Effects of Tungsten Carbide Thermal Spray Coating by HP/ HVOF and Hard Chromium Electroplating on AISI 4340 High Strength Steel. Surf Coat Technol 2001; 138: 113-24.

http://dx.doi.org/10.1016/S0257-8972(00)01148-8

[7] Khedkar J, Khanna AS, Gupta KM. Tribological Behavior of Plasma and Laser Coated Steels. Wear 1997; 205: 220-7.

http://dx.doi.org/10.1016/S0043-1648(96)07291-2

[8] Chandak A, Sivakumar R, Balasubramanian G. Tribological Solutions for Engineering Industries by HVOF-Topgun Spraying in Thermal Spray: Meeting the Challenges of the 21st Century, Proceedings of the 15th International Thermal Spray Conference, C. Coddet, ed., ASM International, Materials Park, $\mathrm{OH}, 1998$. pp. 531-53

[9] Keshavan MK, Kembalyan KT. Wear Characterisation and Practical Applications of Thermal Spray Coatings in Drilling Applications" in Proceedings of the 1993 National Thermal Spray Conference, C.C. Berndt and S. Sampath, ed, ASM International, Materials Park, OH, 1993, pp. 635-41.

[10] Peters JA, Ghasripoor F. Sliding Wear Behavior of Carbide Coatings in Advances in Thermal Spray Science and Technology: Proceedings of the 8th National Thermal Spray Conference, C.C. Berndt and S. Sampath, ed., ASM International, Materials Park, OH, 1995, pp. 38792.

[11] Jia K, Fisher TE, Gallois B. Microstructure, Hardness and Toughness of Nanostructured and Conventional WC-Co Composites. Nanostruct Mater 1998; 10: 875-91. http://dx.doi.org/10.1016/S0965-9773(98)00123-8

[12] Wong TT, Liang GY, He BL, Woo CH. Wear resistance of laser-clad $\mathrm{Ni}-\mathrm{Cr}-\mathrm{B}-\mathrm{Si}$ alloy on aluminium. J Mater Process Technol 2000; 100: $142-6$

http://dx.doi.org/10.1016/S0924-0136(99)00463-X
[13] Rodriguez J, Martín A, Fernández R, Fernández JE. An experimenta study of the wear performance of NiCrBSi thermal spray coatings. Wear 2003; 255: 950-5.

http://dx.doi.org/10.1016/S0043-1648(03)00162-5

[14] Sundararajan T, Kuroda S, Abe F, Sodeoka S. High temperature corrosion of nanoceria coated $9 \mathrm{Cr}-1 \mathrm{Mo}$ ferritic steel in air and steam. Surf Coat Technol 2006; 201: 2124-30. http://dx.doi.org/10.1016/i.surfcoat.2006.02.007

[15] Skulev H, Malinov S, Sha W, Basheer PAM. Microstructural and mechanical properties of nickel-base plasma sprayed coatings on steel and cast iron substrates. Surf Coat Technol 2005; 197: 177-84. http://dx.doi.org/10.1016/i.surfcoat.2005.01.039

[16] Skulev H, Malinov S, Basheer PAM, Sha W. Modifications of phases, microstructure and hardness of Ni-based alloy plasma coatings due to thermal treatment. Surf Coat Technol 2004; 185: 18. http://dx.doi.org/10.1016/j.surfcoat.2003.12.012

[17] Torrance AA. The effect of grit size and asperity blunting on abrasive wear. Wear 2002; 253: 813-9.

http://dx.doi.org/10.1016/S0043-1648(02)00103-5

[18] Moore MA. A review of two-body abrasive. Wear 1974; 27: 1-17. http://dx.doi.org/10.1016/0043-1648(74)90080-5

[19] Cachon L, Sudreau F, Denape J, Lelait L. Tribological qualification of cobalt-free coatings for pressurized water reactor primary-circuit gate valve applications. Surf Coat Technol 1996; 85: 163-9. http://dx.doi.org/10.1016/0257-8972(95)02672-X

[20] Mateos J, Cuetos JM, Vijande R, Fernandez E. Tribological properties of plasma sprayed and laser remelted $75 / 25 \mathrm{Cr} 3 \mathrm{C} 2 / \mathrm{NiCr}$ coatings. Tribol Int 2001; 34: 345-51. http://dx.doi.org/10.1016/S0301-679X(01)00023-8

[21] Kayuk V, Panasyuk A, Grigor'ev O. Reactions of Cr3C2- TiN system materials with nickel-chromium alloys. Powder Metall Met Ceram 2006; 45: 365-70. http://dx.doi.org/10.1007/s11106-006-0091-0

[22] Sundararajan T, Kuroda S, Abe F. Effect of thermal spray on the microstructure and adhesive strength of high-velocity oxyfuel- sprayed $\mathrm{Ni}-\mathrm{Cr}$ coatings on $9 \mathrm{Cr}-1$ Mo Steel. Metall Mater Trans A 2004; 35 3187-99.

http://dx.doi.org/10.1007/s11661-004-0063-2

[23] Dent AH, Horlock AJ, McCartney DG, Harris SJ. Microstructura characterisation of a Ni-Cr-B-C based alloy coating produced by high velocity oxy-fuel thermal spraying. Surf Coat Technol 2001; 139: 24450

\section{http://dx.doi.org/10.1016/S0257-8972(01)00996-3}

[24] Bahrololoom ME, Hoveidaei A. Influence of post-heat treatment and complexing agents on hardness of $\mathrm{Ni}-\mathrm{Cr}$ alloy coatings. Surf Eng 1999; 15: 502-4. http://dx.doi.org/10.1179/026708499101516830

[25] Dawei Z, Li T, Lei TC. Laser cladding of Ni-Cr3C2/ (Ni+Cr) composite coating. Surf Coat Technol 1998; 110: 81-5.

http://dx.doi.org/10.1016/S0257-8972(98)00675-6

[26] Wang TG, Zhao SS, Hua WG, Gong J, Sun C. Design of separation device used in detonation gun spraying system and its effects on the performance of WC-Co coatings. Surf Coat Technol 2009; 203: 163744.

http://dx.doi.org/10.1016/j.surfcoat.2008.12.012

[27] Sarjas H, Goljandin D, Kulu P, Mikli V, Surženkov A, Vuoristo P. Wea resistant thermal sprayed composite coatings based on iron selffluxing alloy and recycled cermet powders. Mater Sci 2012; 18: 34-9.

[28] Shetty HR, Kosel TH, Fiore NF. A study of abrasive wear mechanisms using diamond and alumina scratch tests. Wear 1982 80: $347-76$.

http://dx.doi.org/10.1016/0043-1648(82)90262-9

[29] Corchia M, Delogu P, Nenci F. Microstructural aspects of wearresistant stellite and colmonoy coatings by laser processing. Wear 1987; 119: 137-52. http://dx.doi.org/10.1016/0043-1648(87)90105-0

[30] Otterloo JL, De Mol Van, Hossont JTHM. Microstructure and abrasive wear of cobalt-based laser coatings. Scripta Materialia 1997; 36: 23945.

http://dx.doi.org/10.1016/S1359-6462(96)00346-6

[31] Otterloo JL, De Mol Van, Hossont JTHM. Microstructural features and mechanical properties of a cobalt-based laser coating. Acta Materialia 1997; 45: 1225-36.

http://dx.doi.org/10.1016/S1359-6454(96)00250-9 
Journal of Coating Science and Technology, 2014, Volume 1, No. 2

[32] Lebaili S, Durand-Charee M, Hamar-Thibault $S$. The metallurgical structure of as-solidified Ni-Cr-B-Si-C hardfacing alloys. J Mater Sci 1988; 23: 3603-11

http://dx.doi.org/10.1007/BF00540502

[33] Mohanty M, Smith RW. Sliding wear behavior of thermally sprayed

75/25Cr3C2/NiCr wear-resistant coatings. Wear 1996; 198: 251-66.

http://dx.doi.org/10.1016/0043-1648(96)06983-9
[34]

[35]

Suh NP. Tribophysics, Prentice-Hall, New Jersey, 1986, pp. 63-90.

Martın A, Rodrıguez J, Fernández JE, Vijande R. Sliding wear behavior of plasma sprayed WC-NiCrBSi coatings at different temperatures. Wear 2001; 251: 1017-22.

http://dx.doi.org/10.1016/S0043-1648(01)00703-7 